\title{
Analysis of aerobic testing in basketball referees and heart rate recovery time
}

\section{Análise de teste aeróbico em árbitros de basquetebol $e$ tempo de recuperação de frequência cardíaca}

\author{
Ramiro Marques Inchauspe ${ }^{1}$ \\ (iD) https://orcid.org/0000-0002-4610-3166 \\ Pablo Morales Barbian \\ (D) https://orcid.org/0000-0002-0371-9593 \\ Alejandro Vaquera² \\ (D) https://orcid.org/0000-0003-1018-7676 \\ Flávia Renata de Almeida ${ }^{3}$ \\ (D) https://orcid.org/0000-0003-3066-1013 \\ Cassiano Teixeira ${ }^{1}$ \\ (D) http://orcid.org/0000-0002-7651-3799
}

Abstract - The study analyzed the physical conditioning and the time of recovery of the maximum heart rate of 12 international referees being used the test of 20 meters with beep to evaluate the cardiorespiratory conditioning, with the frequency to control the recovery time of the maximum cardiac post test. The majority of the referees obtained a recovery of heart rate greater than $50 \%$ in 3 minutes, were those that reached the levels of good to excellent in the table of maximum Vo2. Even with some factors influencing their physical performance most of the referees were able to complete the aerobic test and obtained a good recovery of the heart rate, the others that failed to reach the test goal had the HR recovery in 3 minutes much lower than expected, thus highlighting the association of the maximum VO2 level between good and excellent with the recovery of the heart frequency.

Key words: Exercise test; Heart rate; Oxygen consumption.

Resumo - O estudo analisou o condicionamento físico e o tempo de recuperação da frequência cardiaca máxima de 12 árbitros internacionais utilizando-se o teste de 20 metros com beep para avaliar o condicionamento cardiorrespiratório, com a frequência para controlar o tempo de recuperação do pós-teste cardíaco máximo. A maioria dos árbitros obteve uma recuperação de frequência cardíaca superior a 50\% em 3 minutos, foram aqueles que atingiram os niveis de bom a excelente na tabela de VO2 máximo. Mesmo com alguns fatores influenciando seu desempenho físico, a maioria dos árbitros conseguiu completar o teste aeróbico e obteve uma boa recuperação da frequência cardíaca, os outros que não conseguiram atingir a meta de teste tiveram a recuperação da FC em 3 minutos muito abaixo do esperado, Destacando, assim, a associação do VO2 máximo entre bom e excelente com a recuperação da frequência cardíaca.

Palavras-chave: Consumo de oxigênio; Frequência cardiaca; Teste de esforço.
1 Federal University of Health Sciences of Porto Alegre. Porto Alegre, RS. Brazil.

2 University of León. León, Spain.

3 São Judas Tadeu Universty. São Paulo, SP, Brazil.

Received: August 12, 2019 Accepted: February 11, 2020

How to cite this article Inchauspe R, Barbian P, Vaquera A, Almeida F, Teixeira C. Analysis of aerobic testing in basketball referees and heart rate recovery time. Rev Bras Cineantropom Desempenho Hum 2020, 22:e67015. DOI: http://dx.doi. org/10.1590/1980-0037.2020v22e67015

Copyright: This work is licensed under a Creative Commons Attribution 4.0 International License. 


\section{INTRODUCTION}

The low level of physical condition and the low cognitive performance are manifestations of the same pathological process and may be altered by the improvement in the physical condition promoted by the training ${ }^{1}$. Despite this, studies have positively associated cardiorespiratory fitness with cognition, especially in measures of attention, executive function and spatial vision ${ }^{2}$. Among the various components that characterize a person's physical well condition, having a high cardiorespiratory capacity has been a very important factor, both for athletes and non-athletes who seek physical activity for health promotion. Obtaining a regularity of physical activity or physical exercise promotes physical body shape and health benefits, in relation to metabolism, physiological and psychological, besides maintaining heart rate $(\mathrm{HR})$ and low blood pressure in submaximal intensity effort, as well as reduced systolic and diastolic blood pressure at rest ${ }^{3}$.

The relative intensity of aerobic exercise can be quantified through several indicators. Among them, HR, maximum oxygen consumption (VO2max), metabolic equivalent (MET) and subjective perception of effort ${ }^{3,4}$. According to the Léger manual, the 20-meter back-and-forth test is a double-indirect test used to estimate the VO2max value in children, adolescents, and adults. This test is composed of multiple progressive stages of running with increasing intensity that determine the VO2max of the individual. For adults, the prediction of $\mathrm{VO} 2 \mathrm{max}$ can be obtained by having only the maximum aerobic speed of running (Vel, given in $\mathrm{km} / \mathrm{h}$ ) by means of the following formula ${ }^{5}$ VO2 $\max =-27.4+6^{*} \mathrm{Vel}$. There is an adequate relative intensity of effort for improvement in aerobic fitness. HR is used as an intensity regulator in aerobic exercise because it has a direct relationship with the VO2max percentage so that 60 to $90 \%$ of the maximum HR. It is equivalent to approximately 40 to $80 \%$ of the $\mathrm{VO} 2 \mathrm{max}^{6,7}$.

The increase in HR during the execution of a physical exercise, modulated by the sympathetic and parasympathetic nervous system, presents a linear growth, mainly, when the volunteer is submitted to a power with growth in the form of ramp. In the discontinuous step-type protocols, at the beginning of the effort, a heart rate latency period of about 0.5 seconds is documented, followed by a marked increase It is, mostly, due to the reduction of the parasympathetic stimulation on the known sinoatrial nodule as a rapid component of heart rate elevation, which is independent of the applied power intensity ${ }^{8}$. In order to qualify an International Basketball Federation championship (FIBA) referee, candidates must successfully pass the FIBA Referees' Basic Physical Aptitude Test, written and practical, in accordance with the FIBA rules established by the FIBA Technical Commission'. Given the above lack, the objective in this paper was to analyze the cardiorespiratory level and recovery of the maximum post-test heart rate of the FIBA referees in an international basketball competition. 


\section{METHOD}

\section{Design of the study}

The study was designed as a cross-sectional study and was conducted with a group of referees from the International Basketball Federation (FIBA) at the Juan de la Barrera Olympic Gymnasium in Mexico City, Mexico, at the FIBA Americas Championship. Basketball (FIBA), U18 female, from July 30 to August 7, 2018.

\section{Sample}

Twelve referees from the international category, 3 men and 9 women, participated in the survey, composed of the following countries: Argentina (1), Colombia (1), Chile (1), Mexico (2), Canada (1), Guatemala (1), El Salvador (2), Puerto Rico (1), Cuba (1) and United States of America (1). The referees were selected according to the teams that are competing, there are 8 referees from each country plus 4 neutral referees, that the teams are not participating in the games, each of them refereed 6 games, arriving and leaving a day before and later, respectively, of the dates of the games. There is a more aerobic training during the days that are in the competition, performing a race of 3 to $6 \mathrm{~km}$ interspersing the days with a HIT and the functional one.

\section{Data collect}

For data collection there were used the Polar team pro pulsometer was used to measure the heart rate, during and after the test, an Omron bioimpedance device to analyze the BMI of each member measured with 6 hours of fasting on awakening, a Lenoxx CA 340 - 280W Audio Amplifier Loudspeaker, 14 white and orange cones and a white crepe tape to mark lines that mark the exit and arrival of 20 meters (Beep test). The physical test is part of an analysis of the referees' profile and the one that cannot complete the test is below the selection criteria list to referee the most important games, such as a final or second and third place dispute.

FIBA physical fitness coordinator Ramiro Inchauspe applied the tests with the bioimpedance device on the morning of 05/08/2018 in the auditorium of the hotel Holliday Inn Cocoyan where they were staying, starting at 7 hours earlier. The physical test Beep test was applied in the arena of the Olympic Gymnasium Juan de la Barrera arena of the games at 10 o'clock, before the start of the competition. Two batteries were made with 6 referees in each. In the first battery they were all women and in the second, 3 men and 3 women. Men had the aim of completing 10 minutes equivalent to 86 touches and women 8 minutes or 64 touches, these being the protocol required for cardiovascular fitness of the FIBA referees in any competition. The referees were already with the pulsometer throughout the test, to measure the maximum frequency at the end of the test and to notice the recovery time of the maximum frequency from 1 to 3 minutes post-test. The test yoyo lasts for 10 minutes and the referee attempted to 
make as many backs and forth as possible (2X20), respecting the race speed which is indicated by a beep emitted by a CD. The athlete was eliminated when, for the second consecutive time, he fails to reach the indicated marks coinciding with the acoustic signal due to physical wear and tear. The yield will be given by the number of meters reached in the race.

\section{Data analysis}

According to a previous study ${ }^{10}$, the function of data analysis is to organize, provide structure and extract the meanings of the research data. Statistical analysis was performed by the Microsoft ${ }^{\circledR}$ Excel 2002 program through descriptive analysis and comparison between the minimum values, being considered significant values greater than 64 , for women, and greater than 86, for men.

\section{RESULTS}

In table 1 is presented the data referring to which country are the referees. They have an average age of 32 years old and the vast majority are women with an average body mass index (BMI) of all in 24 .

Table 1. Results of data collected from referees during the FIBA Americas U18.

\begin{tabular}{lccccccccc}
\hline COUNTRY & AGE & SEX & BMI & TEST & HR M & $1^{\prime}{ }^{\prime} \mathrm{HR}$ & $3^{\prime} \mathrm{HR}$ & $1^{\prime} \mathrm{HR}^{\prime} \%$ & $3^{\prime} \mathrm{HR} \%$ \\
\hline ARGENTINA & 26 & Female & 21,1 & 76 & 180 & 168 & 146 & 7,14 & 23,29 \\
CANADA & 32 & Female & 25,8 & 52 & 186 & 171 & 126 & 8,77 & 47,62 \\
CHILE & 33 & Male & 27,8 & 98 & 183 & 162 & 118 & 12,96 & 55,08 \\
COLOMBIA & 46 & Male & 25,9 & 108 & 180 & 158 & 116 & 13,92 & 55,17 \\
CUBA & 32 & Female & 21,9 & 82 & 189 & 167 & 122 & 13,17 & 54,92 \\
EL SALVADOR & 35 & Female & 22,9 & 60 & 176 & 158 & 127 & 11,39 & 38,58 \\
EL SALVADOR & 32 & Male & 24,6 & 60 & 174 & 168 & 148 & 3,57 & 17,57 \\
GUATEMALA & 32 & Female & 22,7 & 64 & 206 & 180 & 153 & 14,44 & 34,64 \\
MEXICO & 30 & Female & 26 & 64 & 187 & 163 & 126 & 14,72 & 48,41 \\
MEXICO & 32 & Female & 21,3 & 83 & 174 & 143 & 98 & 21,68 & 77,55 \\
PUERTO RICO & 29 & Female & 28,7 & 60 & 193 & 173 & 135 & 11,56 & 42,96 \\
U.S.A. & 35 & Female & 22 & 70 & 190 & 168 & 123 & 13,10 & 54,47 \\
\hline
\end{tabular}

Note. BMI: body mass index; HR: heart rate; U.S.A.: United States of America.

Those who obtained a recovery of more than $50 \%$ in 3 minutes were the ones that reached the level of excellence in the maximum VO2 table, except for the Argentine participant who has a good maximum V02 but the recovery of the HR is much slower than the too much. In order to determine reference values for maximum $\mathrm{VO} 2$, they generally did not take into account all these factors, in addition to the fact that the formulas most used to predict the maximum VO2 are from studies with very small samples (Figure 1). 


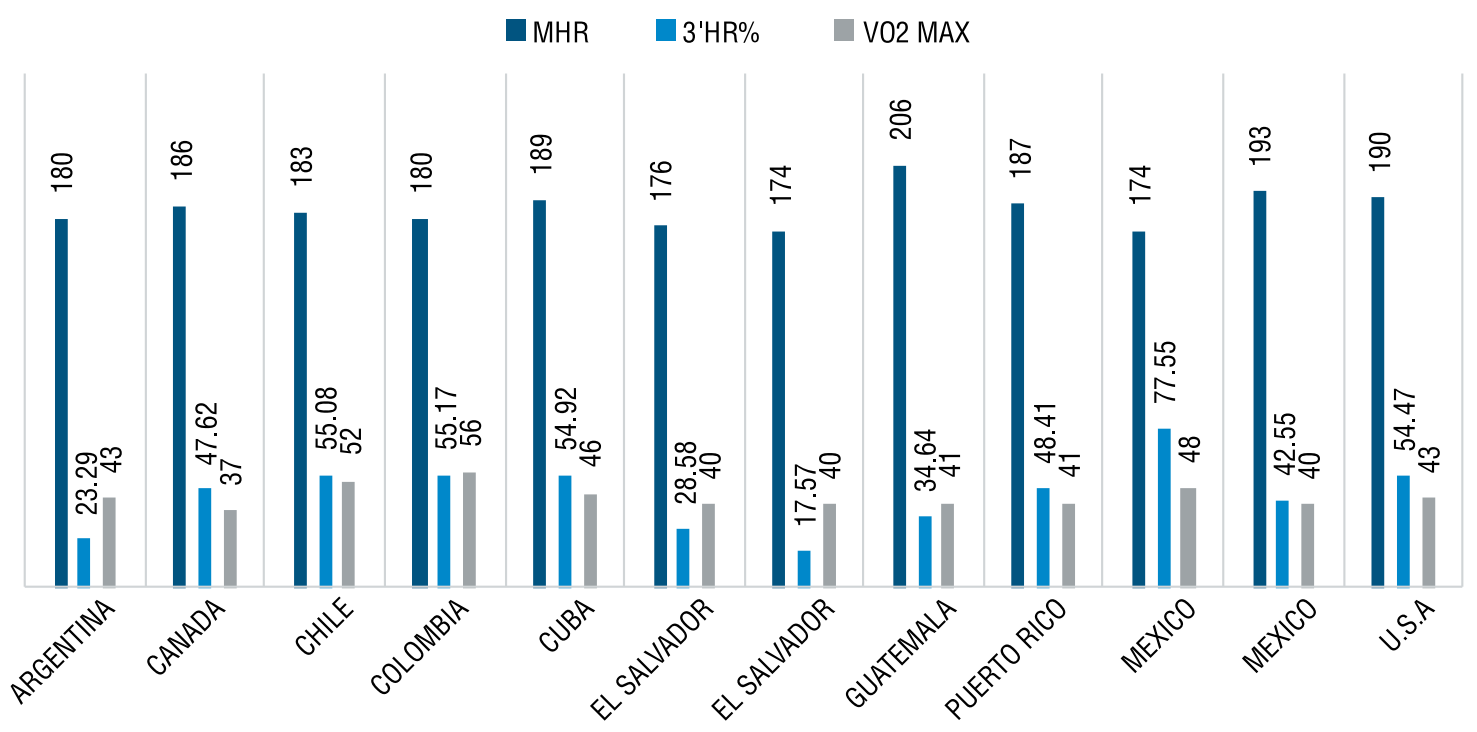

Figure 1. Level of maximum heart rate (MHR), heart recovery in three minutes (3'HR\%), and maximum Oxygen Consumption (VO2 MÁX).

\section{DISCUSSION}

Although the BMI does not provide reliable evidence regarding the amount and distribution of body fat, many studies demonstrated their relevance in assessing mortality risk. In adults, extreme BMI values increase the risk of mortality ${ }^{11}$. In the aerobic test, only the Canadian referees and two from El Salvador did not reach the required minimum level. This test is already part of an important test series in other countries championship, such as EUROFIT, FITNESSGRAM, also known as PACER, where it has been applied in Europe and the USA in the evaluation of schoolchildren, as well as by FIBA for the selection of referees ${ }^{12}$.

The HR recovery of referees from Argentina, Chile, Colombia, Cuba, Mexico, and the United States were considered above the one required by the aerobic test and with the highest percentage of HR recovery in 3 minutes. Post-exercise heart rate recovery is a tool with clinical potential and sports practice application. It is known that a minor recovery of heart rate after exercise is related to a poor prognosis of mortality. In addition, better recovery of heart rate between physical training sessions predisposes a better sports performance ${ }^{10}$. In the table, it is observed that the Argentine referee had an excellent aerobic test, but the recovery of the HR was much lower while compared to the others that also obtained good results in the aerobic test.

As recovery is developing, removal of metabolites produced by muscle contraction (lactate, $\mathrm{H}+, \mathrm{Pi}$...) and circulating catecholamines, return of blood $\mathrm{pH}$ to its basal condition and regularization of body temperature. Such responses produce the recovery of body cells ${ }^{13,14}$. In the present study, there was no significant difference between the two groups.

A good recovery of the HR can be an important factor for the success of the sport since the good performance in a sports activity requires a great recovery of the efforts of the previous activities ${ }^{15,16}$. 
It is observed a correlation between maximum VO2 level and HR. Referees who are classified as good and excellent in the maximum V02 have a greater reduction of the maximum HR in 3 minutes, in particular, was the referee of Mexico who (77\%) of HR recovery in 3 minutes and with excellent V02 at 48. According to previous studies ${ }^{17,18}$, greater blood flow in the brain (i.e. carbohydrates and creatine) results in higher energy intake (i.e. ATP). It can be assumed that this is a probable mechanism by which acute exercise favors cognitive performance and acute and chronic exercise benefits on cognitive performance have been widely reported. Acutely, such effects are probably due to an increase in cerebral blood flow and hence the supply of nutrients. In parallel, there is evidence suggesting that the acute effect of exercise may be mediated by an increase in neurotransmitter activity.

The action of physical exercise on cognitive function can be direct or indirect. Mechanisms that directly act to increase the speed of cognitive processing would be an improvement in the cerebral circulation and alteration in the synthesis and degradation of neurotransmitters. In addition to the direct mechanisms, others mechanisms, such as a decrease in blood pressure, a decrease in the levels of LDL, triglycerides in the blood plasma and inhibition of platelet aggregation seems to act indirectly, improving these functions as well as the general functional capacity, reflecting in this manner in the increase life quality ${ }^{19}$.

Exercise and physical training promote a variety of changes, including cardiorespiratory benefits, as well as increases bone mineral density and decreases the risk of chronic degenerative diseases. Another aspect has gained relevance in the middle of the gain of conditioning: the improvement in cognitive function. Physical exercise improves and protects brain function, suggesting that physically active people are less likely to be affected by mental disorders than sedentary ones. In addition, it is important to note that physical activity is associated with a higher level of cognitive function, which may be related to physical activity ${ }^{20}$.

\section{CONCLUSION}

Whereas being a basketball referee is not a profession and everyone has to have a fixed job to support their families, some with the day to day running cannot get one to train. Even with some factors influencing their physical performance, most of the referees were able to complete the aerobic test and obtained a good recovery of the heart rate, the others that failed to reach the test goal had the HR recovery in 3 minutes much lower than expected, thus highlighting the association of the maximum VO2 level between good and excellent with the recovery of HR.

Further studies with a larger number of referees are suggested to identify whether the test beep meets the requirements of a basketball game and to obtain more relevant information on the association of maximal $\mathrm{HR}$ reduction in 3 minutes taking into account the level of each referee's maximum VO2. 


\section{COMPLIANCE WITH ETHICAL STANDARDS}

\section{Funding}

This research did not receive any specific grant from funding agencies in the public, commercial, or not-for-profit sectors. This study was funded by the authors.

\section{Ethical approval}

This research is in accordance with the standards set by the Declaration of Helsinki.

\section{Conflict of interest statement}

The authors have no conflict of interests to declare.

\section{Author Contributions}

Conceived and designed the experiments: RMI \& AV. Performed the experiments: RMI \& AV. Analyzed the data: RMI \& AV. Contributed reagents/materials/analysis tools: RMI \&AV. Wrote the paper: RMI \&AV.

\section{REFERENCES}

1. Simonsick EM. Fitness and cognition: Encouraging findings and methodological considerations for future work. J Am Geriatr Soc 2003; 51(4):570-1.

2. Barnes DE, Yaffe K, Satariano WA, Tager IB. A longitudinal study of cardiorespiratory fitness and cognitive function in healthy older adults. J Am Geriatr Soc 2003;51(4):459-65.

3. Pescatello I, Linda S, editors. ACSM's guidelines for exercise testing and prescription, 10th Ed. Philadelphia: Lea \& Febiger; 2003.

4. Borg, G. Escalas de Borg para a dor e o esforço percebido, 1st ed. São Paulo: Manole; 2000.

5. Añez CR, Hino A. Manual prático para a aplicação do teste de Vai-e-Vem (20m) de Léger; 2013. [homepage on the internet cited on 2019 May 20. Available at https:/gpaq.com.br/wp-content/uploads/2013/11/Manual-L\%C3\%A9gerModificado-v2.pdf]

6. Powers SK, Howley ED. Fisiologia do exercício: teoria e aplicação ao condicionamento e no desempenho. São Paulo: Manole; 2000.

7. Wilmore JH, Costill DL. Fisiologia do esporte e do exercício. São Paulo: Manole; 2001.

8. Catai AM, Chacon-Mikahil MP, Martinelli FS, Forti VA, Silva E, Golfetti R, et al. Effects of aerobic exercise training on heart rate variability duringwakefulness and sleep and cardiorespiratory responses of young andmiddle-aged healthy men. Braz J Med Biol Res 2002;35(6):741-52.

9. International Federation of Basketball. Operations manual for national member federations; 2017. [homepage on the internet cited on 2019 May 21. Available at http://www.fiba.basketball/en/Module/c9dad82f-01af-45e0-bb85ee4cf50235b4/9cf4fb76-856a-4d04-85e7-1f777ce065a3]

10. Polit DF, Beck CT, Hungler BP. Fundamentos de Pesquisa em Enfermagem, Métodos, avaliação e utilização, 5th ed. Porto Alegre: Artmed; 2004.

11. Zhu S, Heo M, Plankey M, Faith MS, Allison DB. Associations of body mass index and anthropometric indicators of fat mass and fat free mass with all-cause mortality among women in the first and second National Health and Nutrition Examination Surveys follow-up studies. Ann Epidemiol 2003;13(4):286-93. 
12. Duarte M, Duarte CR. Validade do teste aeróbico de corrida de vai-e-vem e 20 metros. Rev Bras Cienc Mov 2001;9(3):7-14.

13. Buchheit M, Papelier Y, Laursen PB, Ahmaidi S. Noninvasive assessment of cardiac parasympathetic function: postexercise heart rate recovery or heart rate variability? Am J Physiol Heart Circ Physiol 2007;293(1):H8-10.

14. Coote JH. Recovery of heart rate following intense dynamic exercise. Exp Physiol 2010;95(3):431-440.

15. Borresen J, Lambert, MI. Autonomic control of heart rate during and after exercise: measurements and implications for monitoring training status. Sports Med 2008;38(8):633-646.

16. Kiviniemi AM, Hautala AJ, Kinnunen H, Tulppo MP. Endurance training guided individually by daily heart rate variability measurements. European J Appl Physiol 2007;101(6):743-751.

17. Ando S, Kokubu M, Yamada Y, Kimura M. Does cerebral oxygenation affect cognitive function during exercise? Eur J Appl Physiol 2011;111(9):1973-1982.

18. Merege Filho CAA, Alves CRR, Sepúlveda CA, Costa AS, Lancha Junior AH, Gualano B. Influência do exercício físico na cognição: uma atualização sobre mecanismos fisiológicos. Rev Bras Med Esporte 2014;20(3):237-241.

19. Cotman CW, Engesser C. Exercise enhances and protects brain function. Exerc Sport Sci Ver 2002;30(2):75-79.

20. Antunes HKM, Santos RF, Cassilhas R, Santos RVT, Bueno OFA, Mello MT. Exercício físico e função cognitiva: uma revisão. Rev Bras Med Esporte 2006;12(2):108-114.

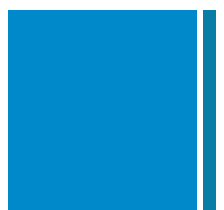

Corresponding author

Ramiro Marques Inchauspe

Federal University of Health Sciences of Porto Alegre. Porto Alegre, RS. Brazil.

Sarmento Leite, $n^{0} 245,90050-170$

Porto Alegre - Brazil

E-mail: ramiro.i@hotmail.com 